\title{
CARDIOVASCULAR RISK IN SUBCLINICAL HYPOTHYROIDISM
}

\author{
Mariana Dobrescuํ, Diana Păun ${ }^{1,2}$, Daniel Grigorie ${ }^{1,2}$, Cătălina Poiană $\breve{a ̆}^{1,2}$ \\ ${ }^{1}$ National Institute of Endocrinology „C.I. Parhon” Bucharest \\ ¿UMF "Carol Davila", Bucharest
}

\section{Summary}

Subclinical hypothyroidism (HSC) is a relatively common thyroid dysfunction, characterized by the increase of the thyroid stimulating hormone (TSH) in the presence of normal free thyroxine values. Thyroid hormones are known for the cardiovascular effects, and the consequences of HSC on the cardiovascular system have become the focus of many studies lately. There are clear indications of the relationship between HSC and cardiovascular risk factors such as hypertension, dyslipidemia and atherosclerosis; also, HSC is associated with metabolic syndrome, BMI increase and cardiac insufficiency. Therefore, many clinical trials investigate the benefits and risks of HSC treatment with L-thyroxine.

Key words: subclinical hypothyroidism, cardiovascular risk factors, L-thyroxine substitution therapy.

\section{Rezumat}

Hipotiroidismul subclinic (HSC) este o disfuncţie tiroidiană relativ frecventă, caracterizată prin creşterea hormonului de stimulare tiroidiană (TSH), în prezenţa valorilor normale ale tiroxinei libere. Hormonii tiroidieni sunt cunoscuţi pentru efectele cardiovasculare, iar consecinţele HSC asupra sistemului cardiovascular au devenit ţinta a numeroase studii în ultima perioadă. Sunt date evidente care indică relaţia dintre HSC şi factorii de risc cardiovascular precum hipertensiunea arterială, dislipidemia şi ateroscleroza; de asemenea, HSC se asociază cu sindromul metabolic, creşterea indicelui de masa corporală şi insuficienţa cardiacă. De aceea, numeroase studii clinice investighează beneficiile şi riscurile tratamentului HSC cu Lthyroxină.

Cuvinte cheie: hipotiroidism subclinic, factori de risc cardiovascular, terapie de substituţie cu L-thyroxină. 


\section{INTERNAL}

\section{General Reviews}

The impact of HSC on the cardiovascular system is the target of numerous studies lately, given that thyroid hormones have multiple actions on the heart and the vascular system.

There are obvious data supporting the relationship between HSC and cardiovascular risk factors such as dyslipidemia, hypertension and sclerosis; there is also conclusive data indicating the association of HSC with metabolic syndrome and heart failure. Therefore, it is very important to identify patients with HSC and increased cardiovascular risk. The risk of progression toward hypothyroidism manifestations is related to a number of factors, such as baseline of serum TSH, auto antibodies, family history, age, sex, race, BMI, dietary iodine intake, presence of goiter. On the other hand, benefits and risks of HSC treatment with L-thyroxine are studied.

\section{Definition}

Subclinical hypothyroidism, the early form of thyroid insufficiency, is characterized by mild deficiency of thyroid hormones and its identification is possible due to the increase in the current performance of thyroid functional tests ${ }^{(2)}$. Most authors define HSC by the isolated increase in serum TSH (thyroid stimulating hormone) $>4-6 \mathrm{mIU} / \mathrm{L}$ in the presence of normal levels of FT4 (free thyroxine) and T3 (triiodothyronine) $)^{(2,3,4,5)}$. However, the exact definition and clinical significance of HSC is confronted with controversy over the correct upper limit of the baseline of serum TSH. A classification of HSC in mild and severe form is also attempted, depending on the serum TSH elevation:

- medium form - TSH 4.5-9 mU/l

- severe form - TSH $\geq 10 \mathrm{mU} / \mathrm{l}$.

\section{Etiology}

The most common cause of HSC $(60-80 \%)$ is chronic autoimmune thyroiditis associated with the presence of anti-thyroid antibodies (anti-thyroid peroxidase antibodies - ATPO), which are characteristics of chronic lymphocytic Hashimoto thyroiditis ${ }^{(3)}$. This is more common in women, but the incidence increases with age for both sexes ${ }^{(1)}$. Increased titre of thyroid auto antibodies and / or serum TSH $>6 \mathrm{ml} / \mathrm{L}$ are solid arguments for the diagnosis of the disease and indicate possible progression to manifest hypothyroidism.

Other causes of HSC can be ${ }^{(1)}$ :

- inappropriate substitution treatment for manifest thyroid insufficiency;

- low compliance with treatment;

- inappropriate monitoring of treatment;

- drug interaction 


\section{Prevalence}

Prevalence of ischemic hypothiothyroidism varies according to the type of population, age, gender, race, geographical area and method of TSH measurement, and it is necessary to standardize the normal reference level for TSH at each specialized laboratory ${ }^{(1)}$. The HSH prevalence is relatively high, in $4-15 \%$ of the general population, with older, elderly and deficient iodine ${ }^{(5,6,8,9)}$ being higher, up to $20 \%$. The average form can be found in approximately $75 \%$ of HSC patients.

\section{Diagnosis}

Diagnosis of hypothyroidism is biochemical and is based on TSH, FT4 dosing and the exclusion of other causes of TSH elevation. Although HSC has high prevalence, there is currently no consensus on screening for this type of dysfunction and the benefits of treatment, and the establishment of a consensus requires long-term clinical studies.

Clinical symptoms are usually absent or unspecific. The reduction in thyroid hormone levels, even minor, is recognized promptly by the anterior pituitary gland; it is extremely sensitive to small changes in thyroid hormone serum levels and secretes an additional amount of TSH through the feedback mechanism. It is also possible for tissues other than the anterior pituitary gland to recognize the suboptimal level of thyroid hormones ${ }^{(2)}$. Prospective studies have shown that TSH level 1-1.9 mIU/I indicates the lowest thyroid dysfunction score and TSH increase $>2 \mathrm{mIU} / \mathrm{I}$ is associated with an increase in hypothyroidism $^{(3)}$. HSD may persist for years or may develop into myxoedema, especially in persons with autoimmune thyroidism and high titre of thyroid autoantibodies ${ }^{(4)}$ The risk of progression to manifest hypothyroidism (3-8\% per year) is related to multiple factors such as $\mathrm{TSH}>6 \mathrm{mIU} / \mathrm{l}$, the presence of autoantibodies and their high titre, family history, age, sex, race, BMI, iodine intake, and presence of goiter ${ }^{(1,2)}$.

\section{Cardiovascular risk factors in subclinical hypothyroidism}

Numerous studies indicate the relationship between HSC and the unfavorable lipid profile and the beneficial effects of Lthyroxine treatment on the lipid profile. At the same time, there are indications that treatment can improve other markers associated with cardiovascular disease, such as endothelial function. However, there is no unanimous opinion on the interaction between HSC and cardiovascular risk.

- HSC as manifest form is associated with dyslipidemia. It correlates positively with serum TSH and has an atherogenic intense profile: total serum cholesterol, LDLcholesterol and triglycerides are elevated and HDL-cholesterol is low. Cholesterol elevation is mainly due to the increase in LDL concentration due to decreased LDL receptor count and activity in the liver and therefore LDL catabolism, and thyroid failure also favors the oxidation of LDL particles, thereby increasing their atherogenic effect. Increase in triglycerides is induced by the promotion of esterification of fatty acids in the liver. In addition, lipoprotein lipase activity is reduced in thyroid insufficiency resulting in a decrease in triglyceride-rich clearance of ureilipoproteins, hypertri-glyceridemia, VLDL elevation and sometimes postprandial growth of chylomicrons. At 


\section{INTERNAL}

\section{General Reviews}

the same time, low levels of HDL are found in HSC, a decrease in the plasma clearance rate of HDL in the liver cell ${ }^{(7)}$. Through all these mechanisms, HSC may be one of the causes of secondary hyperlipidemia and is a risk factor independent of atherosclerosis along with many other factors including obesity, hypertension, diabetes. Therefore, there is interest in using thyroid hormone therapy to treat HSC-associated dyslipidemia, but also in familial hypercholesterolemia and obesity.

- Subclinical hypothyroidism is associated with increased inflammatory markers, which together with dyslipidemia promotes increased cardiovascular risk and clinical manifestations associated with it. Reactive C protein (CRP), interleukin-6 (IL-6), tumor necrosis factor $\alpha$ (TNF $\alpha$ ) were studied, and their level increased as progression of hormone deficiency and lack of substitution treatment.

- The action of thyroid hormones on insulin sensitivity is of great interest, but the current results are still contradictory. Hypothyroidism is associated with disorder of glucose and insulin metabolism manifested by alteration of insulin secretion during glucose loading, hyperinsulinemia, glycemic disorders and insulin resistance (IR). IR indicates the presence of a low peripheral tissue response to endogenous insulin secretion and promotes elevated hepatic cholesterol production, VLDL and increased HDL cholesterol clearance. Therefore, the association of serum TSH increased by IR increases the risk of dyslipidemia and contributes to increased cardiovascular risk in hypothyroidism. The predisposition of patients with HSC to IR is demonstrated by numerous studies. The mechanism of this association is unclear, but generic studies have described some gene polymorphisms in these patients ${ }^{(16,17,18)}$.

- Endothelial dysfunction, one of the early signs of sclerosis, has been observed in $\operatorname{HSC}^{(19,20,21)}$. Numerous multicenter studies have indicated an increased risk of atherosclerosis in people with HSC. Multiple lipid plaques in the large artery wall have been identified in patients with HSC, comparable to those seen in the elderly with other risk factors such as hypercholesterolemia, hypertension, smoking and diabetes. Also, the incidence of myocardial infarction or congestive heart failure has been increased in the elderly with $\mathrm{TSH}>7 \mathrm{mU} / \mathrm{I}^{(22,23,24,25)}$. In manifest or subclinical hypothyroidism, endothelial nitric oxide (NO) activity - the major biological marker of endothelial dysfunction - is reduced and is associated with decreased vasodilatation induced by various stimuli and accelerated atherogenesis. Endothelial function is 
accelerated in HSC by the interaction of multiple mechanisms:

- hyperlipidemia, especially post-prandial, favors serum LDL growth, subintimal lipid deposits, which may disrupt NO synthesis in endothelial cells, with worsening of endothelial dysfunction;

- chronic inflammation;

- oxidative stress that is favored by chronic inflammation; there are also observations that demonstrate the direct effect of TSH to promote oxidative stress ${ }^{(26)}$; it has profoundly unfavorable effects on NO synthesis in endothelial cells with endothelial dysfunction;

- Insulin resistance (IR) frequently accompanies dyslipidemia, chronic inflammation and oxidative stress, especially in the context known as metabolic syndrome; IR favors endothelial dysfunction either indirectly through the other components of the metabolic syndrome or directly by disrupting the production of $\mathrm{NO}$ and endothelin-1 at the endothelium level ${ }^{(27)}$.

- The action of TSH on extratiroidal TSH receptors identified in: liver (promotes cholesterol synthesis), adipocytes (induces synthesis of interleukin-6 - IL6 ), bone marrow (induces secretion of tumor necrosis factor $\alpha$ - TNF $\alpha$ ), endothelial cells (these recently identified endothelial cell receptors could be a direct mechanism of endothelial dysfunction).

\section{Cardiovascular disease in subclinical hypothyroidism}

Thyroid deficiency is associated with HTA, atherosclerosis / coronary artery disease, heart failure and increased cardiovascular mortality ${ }^{(22,23,24,25)}$. The elevated level of TSH plays an important role in the mechanisms that induce atherosclerosis and its progression $^{(28)}$ :

- hyperlipaemia, oxidative stress, chronic inflammation, insulin resistance;

- endothelial dysfunction;

- proliferation of vascular smooth muscle cells.

However, there is no unanimous acceptance of these actions, and chronic atherosclerosis, being a chronic disease, long-term studies are needed to track histopathological changes related thereto. Recent studies highlight the positive correlation between serum TSH levels and the presence of coronary calcifications assessed by calcium arterial coronary score (CACS) $)^{(29,30,31,32) .}$ Maintenance of TSH within normal limits balances plasma lipid balance and delays progression of sclerosis $^{(33,34)}$. L-thyroxine correction treatment in early stages of HSC with decreased TSH has favorable effects on endothelial function, lipid balance, and haemodynamic changes.

Numerous studies suggest that HSC induces profound effects on cardiac structure and function with decreased myocardial contractility and relaxation, altered left ventricle diastolic function, cardiac output, and heart rate. Cardiac insufficiency is a possible manifestation in HSC by reducing systolic function and diastolic dysfunction of the left ventricle due to decreased left ventricle relaxation with critical impairment of ventricular filling during exercise. The risk of heart failure increases with elevated TSH, and this is more common in the elderly with high cardiovascular risk; in these cases, Lthyroxine substitution treatment has favorable effects, and recent studies of spectroscopic RM have shown that HSC's bio- 


\section{INTERNAL}

\section{General Reviews}

energetic deficit is reversible under $\mathrm{T} 4$ treatment $^{(35,36,37)}$.

\section{Relationship between serum TSH and HTA}

The prevalence of HTA in HSC is significantly higher than in the elderly, and the HTA risk was significantly higher after correction of age, sex, smoking, the HOMA-IR (homeostatis modem assessment of insulin resistance) index and BMI (body mass index). The increase in TA in hypothyroidism is explained by multiple mechanisms ${ }^{(38,39)}$ :

- increased systemic vascular resistance attributed in part to decreased T3 (T3 produces vasodilatation by direct action on smooth muscle cells); it has also been shown that increased TSH favors the proliferation of vascular smooth muscle cells and endothelial dysfunction ${ }^{(40,41)}$;

- abnormalities in sodium metabolism;

- increased levels of catecholamines and SN Simpatic activity;

- decrease in glomerular filtration rate and increase in total water and salt content;

- TA sensitivity to salt-mediated, in part, by vascular action of T3.

- increased risk of atherosclerosis due to associated anomalies: hypercoagulability, increased blood viscosity, lipid abnormalities; in this way, hypothyroidism also influences $T^{(42,43)}$.

Pericarditis may be common in hypothy- roidism in general and rarely in HSC, and therefore thyroid insufficiency should be considered as a possible etiology in the detection of pericardial fluid. The incidence of pericarditis is correlated with the severity and duration of thyroid insufficiency: in severe hypothyroidism, pericarditis is frequently reported with a variable incidence of 30 to $80 \%$ and in HSC the incidence is 3 to $25 \%$ of cases. In the HSC, small / medium quantities of pericardial fluid may be detected, unlike myxedema, where medium or large amounts of liquid may develop, reaching up to cardiac tamponade. The onset and fluid evolution is insidious and asymptomatic in general, and the diagnosis is echocardiographic. The fluid is exudated and biochemically rich in mucopolysaccharides and cholesterol. The occurrence of pericardial fluid in hypothyroidism is linked to multiple mechanisms:

- hygroscopic extravasation of albumin and mucopolysaccharides in the pericardial cavity;

- increased capillary permeability;

- decrease of lymphatic drainage;

- increased water and salt retention.

Regression of pericardial fluid in hypothyroidism is slow (weeks or months), in parallel with L-thyroxine replacement therapy, and the pericardium is usually thickened due to prolonged fluid persistence or recurrence. However, the evolution towards constriction is extremely rare 
because the fibrous pericardium is not infiltrated or inflamed. For all these characteristic elements, HSC should be considered when detecting small / medium quantities of pericardial fluid, sometimes persistent or recurrent. Metabolic syndrome is characterized by abdominal obesity, insulin resistance / glucose intolerance, dyslipidemia, hypertension and is associated with increased cardiovascular risk and mortality. Numerous population studies have observed the association of metabolic syndrome with $\operatorname{HSC}^{(44,45)}$. The imbalance between the hypothalamus, pituitary, thyroid, and adipose tissue is responsible for the pathophysiological mechanisms of HSC association with obesity in metabolic syndrome ${ }^{(46)}$. The association of subclinical hypothyroidism with the increase of BMI and obesity is demonstrated by many studies, but the causal relationship between TSH and BMI is not clear, with other factors such as age, gender, smoking, drug use, non-thyroid disorders being involved. This relationship is supported by numerous arguments about the association between thyroid function, body weight and adipose tissue. In general, hypothyroidism is associated with a reduction in metabolic rate and lipid and carbohydrate metabolism disorders. On the other hand, obesity is associated with thyroid dysfunction and dyslipidemia. Body mass was shown to be a major determinant of thyroxine demand, and increased body mass may require increased TSH thyroid gland stimulation to maintain normal serum thyroxine levels ${ }^{(47)}$. The intimate mechanism of altering thyroid function in obesity was linked to the adaptation to increased energy consumption of obesity, and the increase in TSH was explained by multiple mechanisms ${ }^{(48)}$ :

- HSC produced by iodine deficiency;

- autoimmune thyroiditis;
- mutations of the TSH gene and the presence of TSH receptors for thyroid hormones in the adipose tissue;

- increased leptin-mediated production of prothytrophin;

- resistance to thyroid hormones;

- mitochondrial dysfunction;

- insulin resistance - an essential mechanism in thyroid dysfunction, metabolic syndrome and type 2 diabetes;

- the involvement of thyroid hormones in lipogenesis and lipolysis mediated by the local level of noradrenaline and / or by the post-receptor adrenergic signal pathways;

- the influence of adipose tissue and caloric intake on TSH synthesis and thyroid hormones: for example, weight loss has been shown to be associated with TSH reduction. The mechanism of this relationship seems to be related to the leptin secretion by adipose tissue; leptin stimulates TSH biosynthesis in vitro and synchronization of leptin secretion and $\mathrm{TSH}^{(49,50,51)}$ has been demonstrated.

\section{Treatment with L-thyroxine - benefits and risks}

L-thyroxine substitution therapy in HSC increases the FT4 and FT3 levels and reduces pituitary secretion of TSH through the negative feedback mechanism. The beneficial effects of substitution therapy concern the decrease in vascular resistance and markers of progression of atherosclerosis, improve TA and dyslipidemia. Numerous studies report the decrease in total cholesterol, LDL-cholesterol, and improvement in endothelial function with decreased progression of atherosclerosis. However, there is currently no consensus on the benefit of substitution therapy in HSC, especially in older people at high cardiovascular risk. Hormone therapy itself 


\section{INTERNAL}

\section{General Reviews}

may have adverse effects, especially atrial fibrillation and osteopenia, especially in the elderly ${ }^{(53,54,55)}$. Substitution treatment is indicated in symptomatic or at risk of progression to manifest hypothyroidism, pregnancy, infertility. Recent guidelines on the management of patients with TSH $<10 \mathrm{mIU} / \mathrm{l}$ suggest that the therapeutic decision should be based on patient age, associated risk factors and co-morbidity. Moreover, many authors consider that L-thyroxine substitution treatment is warranted only at people with TSH $>10 \mathrm{mIU} / \mathrm{l}$, the authors say that the treatment recommendation should be correlated with the benefits of L-tyrosine substitution and associated risks.

\section{Conclusion}

In conclusion, serum TSH elevation is an early marker of tissue hypothyroidism when T3 and T4 are within normal limits. The favorable effect of diagnosis and treatment of HSC is related to two consequences with an impact on the state of health:

- preventing progression toward manifested hypothyroidism;

- reducing the risk of cardiovascular morbidity and mortality.

It is currently known that HSC may be one of the causes of secondary hyperlipidemia, and TSH levels correlate positively with inflammatory markers and dyslipidemia and thus contribute to an increased risk of developing cardiovascular disease. Thus, HSC can be considered as an independent risk factor for atherosclerosis along with obesity, hypertension, diabetes. Therefore, knowing the prevalence and risk factors for HSC could influence risk factors and prevent cardiovascular disease. On the other hand, the relationship between HSC and cardiovascular risk factors correlates with increased interest in the use of thyroid hormones in many pathological conditions such as HSCassociated dyslipidemia, obesity and familial hypercholesterolemia. However, the overall significance of HSC remains controversial, and its influence on potential cardiovascular risk factors still requires extensive clinical trials.

\section{Bibliography}

1. Cooper DS, Biondi B. Subclinicalthyroiddisease. Lancet 2012;379:1142-1154.

2. Surks MI, Ortiz E, Daniels GH, Sawin CT, Col NF, Cobin RH, et al. Subclinicalthyroiddisease: scientific review and guidelines for diagnosis and management. JAMA 2004;291:228-238.

3. Biondi B, Cooper DS. The clinicalsignificance of subclinical thyroid dysfunction. EndocrRev 2008;29:76-131.

4. Park YJ, Lee YJ, Choi SI, Chun EJ, Jang HC, Chang HJ. Impact of subclinical hypothyroidism on the coronary artery disease in apparently healthy subjects. Eur J Endocrinol 2011;165:115-121.

5. Kim YA, Park YJ. Prevalence and risk factors of subclinical thyroid disease. EndocrinolMetab (Seoul) 2014;29:20-29.

6. Canaris GJ, Manowitz NR, Mayor G, Ridgway EC. The Colorado thyroid disease prevalence study. Arch Intern Med 2000;160:526-534.

7. Kim TH, Choi HS, Bae JC, Moon JH, Kim HK, Choi SH, et al. Subclinical hypothyroidism in addition to common risk 
scores for prediction of cardiovascular disease: a 10-year community-based cohort study. Eur J Endocrinol 2014;171:649-657.

8. Vanderpump MP, Tunbridge WM, French JM, Apple-ton D, Bates $D$, Clark F et al. The incidence of thyroid disorders in the community: a twenty year follow-up of the Whickham Survey. Clin Endocrinol (Oxf) 1995;43:55-68.

9. Teng W, Shan Z, Teng X, Guan H, Li Y, Teng D et al. Effect of iodine intake on thyroid diseases in China. NEngl J Med 2006;354:2783-2793.

10. Al Sayed A, Al Ali $N$ and Alfadhli E. Subclinical hypothyroidism is associated with early insulin resistance in Kuwaiti women. EndocrJ 2006;53:653-657.

11. Ridker PM, RifaiN, Stampfer MJ and Hennekens $\mathrm{CH}$. Plasma concentration of interleukin- 6 and the risk of future myocardial infarction among apparently healthy men. Circulation2000;101:1767-1772.

12. Esper RJ, Nordaby RA, Vilariño JO, Paragano A, Cacharrón JL, Machado RA. Endothelial dysfunction: a comprehensive appraisal. Cardiovasc Diabetol2006; 5:4-22.

13. Widlansky ME, Gokce N, Keaney JFJr, Vita JA. The clinical implications of endothelial dysfunction. J Am Coll Cardiol2003;42:1149-1160.

14. Frank PG, Pavlides S, Lisanti MP. Caveolae and transcytosis in endothelial cells: role in atherosclerosis. CellTissue Res2009;335:41-47.

15. Tseng FY, Lin WY, Lin CC, et al. Subclinical hypothyroidism is associated with increased risk for all cause and cardiovascular mortality in adults. J Am CollCardiol 2012;60:730-737.

16. Gen R, Akbay $E$ and Sezer $K$. Insulin resistance and cardiovascular risk factors in patient with mild and severe subclinical hypothyroidism. The Endocrinologist 2010;20:128-130.

17. Maratou E, Hadjidakis DJ, Kollias A, et al. Studies of insulin resistance in patients with clinical and subclinical hypothyroidism. EurJ Endocrinol 2009;160:785-790.

18. Peeters RP, Van DerDeure WM, Van Den Beld AW, et al. The Asp727Glu polymorphism in the TSH receptor is associated with insulin resistance in healthy elderly men. Clin Endocrinol (Oxf) 2007;66:808-815.

19. XiangGD, Xiang LW, He HL and Zhao LS. Postprandial lipaemia suppresses endothelium-dependent arterial dilation in patients with hypothyroidism. Endocrine 2012;42:391-398.

20. Taddei $S$, Caraccio $N$, Virdis $A$, et al. Low grade systemic inflammation causes endothelial dysfunction in patients with Hashimoto's thyroiditis. J Clin EndocrinolMetab 2006;91:5076-5082.

21. Zhang C, Xu X, Potter BJ, et al. TNF-alpha contributes to endo-thelial dysfunction in ischemia/reperfusion injury. ArteriosclerThrombVasc Biol 2006;26:475-480.

22. Hak AE, Pols HA, Visser TJ, Drexhage HA, Hofman A and Witteman JC. Subclinical hypothyroidism is an independent risk factor for atherosclerosis and myocardial infarction in elderly women: the Rotterdam study. Ann Intern Med 2000;132:270-278.
23. Rodondi $N$, Newman AB, Vittinghoff E, et al. Subclinical hypothyroidism and the risk of heart failure, other cardiovascular events, and death. Arch Intern Med 2005; 165:2460-2466.

24. Walsh JP, Bremner AP, Bulsara MK, et al. Subclinical thyroid dysfunction as a risk factor for cardiovascular disease. Arch Intern Med 2005;165:2467-2472.

25. Razvi S, Weaver JU, Vanderpump MP and Pearce SH. The incidence of ischemic heart disease and mortality in people with subclinical hypothyroidism: reanalysis of the Whickham Survey cohort. J Clin EndocrinolMetab 2010;95:1734-1740.

26. Dardano A, Ghiadoni L, Plantinga Y, et al. Recombinant human thyrotropin reduces endothelium dependent vasodilation in patients monitored for differentiated thyroid carcinoma. J Clin EndocrinolMetab 2006;91:41754178.

27. Kim YA, Montagnani M, Koh KK and Quon MJ. Reciprocal relationships between insulin resistance and endothelial dysfunction molecular and pathophysiological mechanisms. Circulation 2006;113:1888-1904.

28.Kvetny J, Heldgaard PE, Bladbjerg EM, Gram J. Subclinical hypothyroidism is associated with a low grade inflammation, increased triglyceride levels and predicts cardiovascular disease in males below 50 years. Clin Endocrinol (Oxf) 2004;61:232-238.

29. Rodondi N, den Elzen WP, Bauer DC, Cappola AR, Razvi $S$, Walsh JP, Asvold BO, lervasi G, Imaizumi M, Collet TH et al. Subclinical hypothyroidism and the risk of coronary heart disease and mortality. Journal of the American Medical Association 2010;304:1365-1374.

30. Gencer B, Collet TH, Virgini V, Auer $R \&$ Rodondi $N$. Subclinical thyroid dysfunction and cardiovascular outcomes among prospective cohort studies. Endocrine, Metabolic \&ImmuneDisorders Drug Targets 2013;13:4-12. 31. McQuade C, Skugor M, Brennan DM, Hoar B, Stevenson $C \&$ Hoogwerf BJ. Hypothyroidism and moderate subclinical hypothyroidism are associated with increased all-cause mortality independent of coronary heart disease risk factors: a précis database study. Thyroid 2011;21: 837-843.

32. Taylor PN, Razvi S, Pearce SH, Dayan CM. Clinical review: a review of the clinical consequences of variation in thyroid function within the reference range. J Clin EndocrinolMetab 2013;98:3562-3571.

33. Detrano R, Guerci AD, Carr JJ, Bild DE, Burke G, Folsom $A R$ et al. Coronary calcium as a predictor of coronary events in four racial or ethnic groups. New England Journal of Medicine 2008;358:1336-1345.

34. Geng $H$, Zhang $X$, Wang $C$, et al. Even mildly elevated TSH is associated with an atherogenic lipid profile in postmenopausal women with subclinical hypothyroidism. EndocrRes2014;28:625-631.

35. Brenta G, Mutti LA, Schnitman M, Fretes $O$, Perrone $A$, Matute ML. Assessment of left ventricular diastolic function byradionuclideventriculography at rest and exercise in subclinical hypothyroidism, and its response to L-thyroxine therapy. AmJ Cardiol2003;91:1327-1330. 


\section{INTERNAL}

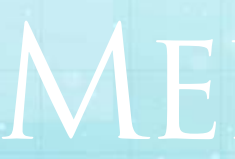

General Reviews

36. Nanchen D, Gussekloo J, Westendorp RG, Stott DJ, Jukema JW, Trompet $S$, et al. Subclinical thyroid dysfunction and the risk of heart failure in older persons at high cardiovascular risk. J Clin Endocrinol Metab2012;97:852-861.

37. Madathil A, Hollingsworth KG, Blamire AM, Razvi S, Newton JL, Taylor $R$, et al. Levothyroxine improves abnormal cardiac bioenergetics in subclinical hypothyroidism: a cardiac magnetic resonance spectroscopic study. J Clin Endocrinol Metab2015;100:E607-E610.

38. Iqbal A, Figenschau $Y$, Jorde R. Blood pressure in relation to serum thyrotropin: the Tromsø study. J HumHypertens 2006;20:932-936.

39. Liu D, Jiang F, Shan Z, Wang B, Wang J, Lai Y, et al. A cross sectional survey of relationship between serum TSH level and blood pressure. J HumHypertens 2010;24:134-138.

40. Monzani F, Caraccio N, Kozakowa M, et al. Effect of levothyroxine replacement on lipid profile and intima media thickness in subclinical hypothyroidism: a double blind, placebo-controlled study. J Clin Endocrinol Metab2004;89:2099-2106.

41. Oner FA, Yurdakul S, Oner E, Uzum AK, Erguney $M$. Evaluation of the effect of L-thyroxin therapy on endothelial functions in patients with subclinical hypothyroidism. Endocr Res2011;40:280-284.

42. Cappola AR, Ladenson PW. Hypothyroidism and atherosclerosis. J Clin EndocrinolMetab 2003;88:2438-2444.

43. Saltiki K, Voidonikola P, Stamatelopoulos K, MantzouE, Papamichael C, Alevizaki M. Association of thyroid function with arterial pressure in normotensive and hypertensive euthyroid individuals: a cross sectional study. ThyroidRes 2008;29:3-9.

44. Iwen KA, Schroder E, Brabant G. Thyroid hormones and the metabolic syndrome. EurThyroid J 2013;2:83-92.

45. Nakajima Y, Yamada M, Akuzawa M, Ishii S, Masamura $Y$, Satoh $T$, et al. Subclinical hypothyroidism and indices for metabolic syndrome in Japanese women: one year followup study. J Clin EndocrinolMetab 2013;98:3280-3287.

46. Suh S, Lee MK. Metabolic syndrome and cardiovascular disease in Korea. J. Atheroscler. Thromb 2014;21(Suppl 1):S31-S35.

47. Sari R, Balci MK, Altunbas H, Karayalcin U. The effect of bodyweight and weight loss on thyroid volume and function in obese women. Clin Endocrinol 2003;59:258-262.

48. Rosenbaum M, Hirsch J, Murphy E, Leibel RL. Effects of changes in body weight on carbohydrate metabolism, catecholamine excretion, and thyroid function. Am J Clin Nutr 2000; 71:1421-1432.

49. Auwerx J, Staels B. Leptin. Lancet 1998; 351:737-742.

50. Ortiga-Carvalho TM, Oliveira KJ, Soares BA, PazosMoura CC. The role of leptin in the regulation of TSH secretion in the fed state: in vivo and in vitro studies. J Endocrinol 2002;174: 121-125.

51. Ghizzoni L, Mastorakos G, Ziveri M, Furlini M, Solazzi A, Vottero $A$ et al. Interactions of leptin and thyrotropin 24-h secretory profiles in short normal children. J Clin EndocrinolMetab 2001;86:2065-2072.

52. Ye Y, Xie H, Zeng Y, Zhao X, Tian Z, Zhang S. Association between subclinical hypothyroidism and blood pressure: a meta-analysis of observational studies. EndocrPract 2014;20:150-158.

53. Razvi S, Ingoe L, Keeka G, Oates C, McMillan C and Weaver LU: The beneficial effect of L-thyroxine on cardiovascular risk factors, endothelial function, and quality of life in subclinical hypothyroidism: randomized, crossover trial. J Clin EndocrinolMetab 2007;92:17151723.

54. Razvi S, WeaverJU, Butler TJ, Pearce SH. Levothyroxine treatment of subclinical hypothyroidism, fatal and nonfatal cardiovascular events, and mortality. Arch Intern Med2012;178:811-817.

55. Pasqualetti G, Tognini S, Polini A, Caraccio N, Monzani F. Is subclinical hypothyroidism a cardiovascular risk factor in the elderly? J Clin Endocrinol Metab2013;98:2256-2266. 